Original Article

\title{
FORMULATION STRATEGY, STABILITY ISSUES, SAFETY AND EFFICACY EVALUATIONS OF ACACIA CATECHU WHITENING CREAM
}

\author{
ORAPHAN ANURUKVORAKUN ${ }^{*}$, RACHADAPORN BOONRUANG ${ }^{2}$, NARONGRIT LAHPUN ${ }^{1}$
}

${ }^{1}$ Department of Cosmetic Science, Phranakorn Rajabhat University, Bangkok, Thailand, ${ }^{2}$ Department of Business Administration, Phranakorn Rajabhat University, Bangkok, Thailand

Email: aoraphan@yahoo.com

Received: 03 Nov 2018, Revised and Accepted: 09 Jan 2019

\section{ABSTRACT}

Objective: To investigate among formulation strategy, stability issues, safety and efficacy (tyrosinase inhibitory activity and sun protection) of a novel whitening cream containing Acacia catechu heartwood extract.

Methods: The tyrosinase inhibitory activity of the A. catechu extract was investigated using L-DOPA as a substrate. A combination of silicone and three photo-protective filters; natural UV filter (A. catechu extract), chemical and physical filters, was formulated and evaluated. The Sun Protection Factor (SPF), stability, skin allergy or irritation, and the satisfaction of the developed whitening creams, were investigated.

Results: The A. catechu extract showed the strong tyrosinase inhibitory activity with the percentage of inhibition of $61.58 \%$ at the concentration of $120 \mu \mathrm{g} / \mathrm{ml}$ compared to a positive control of kojic acid (98.73\% inhibition) at the same concentration of $120 \mu \mathrm{g} / \mathrm{ml}$. impressively, the highest SPF of A. catechu whitening cream with physical and chemical UV filters was 30 . While, the highest SPF of the $A$. catechu whitening cream without those filters, was 24. No changes in color, liquefaction and phase separation were observed for the developed whitening cream when stored in the refrigerator. Among the twenty volunteers, eighteen volunteers had no skin irritation, while one of them had redness (Transient) and then another one had erythema or very slight irritation to the developed whitening creams. Besides, there was no statistically significant difference for the satisfaction between $A$. catechu whitening creams and commercial whitening creams ( $p>0.05)$.

Conclusion: Obviously, A. catechu whitening creams had very high efficacy, stability, and safety for being a commercial product in a near future.

Keywords: Acacia catechu, Tyrosinase inhibitory activity, Stability, Efficacy

(c) 2019 The Authors. Published by Innovare Academic Sciences Pvt Ltd. This is an open-access article under the CC BY license (http://creativecommons.org/licenses/by/4.0/) DOI: http://dx.doi.org/10.22159/ijap.2019v11i2.30632

\section{INTRODUCTION}

Broad-spectrum ultraviolet radiation (UVR) is known to be a human carcinogen based on sufficient evidence from numerous studies. The UV radiation is divided into three bands: UVA (320-400 nm), UVB (290-320 nm), and UVC (200-290 nm) [1-2]. UVA radiation reaches the deeper layers of the epidermis and dermis and provokes the premature aging of the skin. UVB radiation is not completely filtered out by the ozone layer and is responsible for the damages due to sunburn [2]. UVC radiation is filtered by the atmosphere before reaching to the earth. Organic filters are molecules that interfere with incident radiation through the mechanism of absorption. Upon returning to the stable state (unexcited), the release of energy occurs at a longer wavelength. The process can be repeated numerous times by a mechanism called resonance. Depending on their capacity to absorb shorter or longer wavelengths, organic filters subclassified into UVA filters, UVB filters and filters for broad-spectrum protection (UVA and UVB). Natural substances extracted from plants have recently been considered, as potential whitening cream resources because of their ultraviolet ray absorption in the UVA and $B$ region and their antioxidant activity [1].

Thus, there are more interesting in the use of natural sources in whitening creams to provide supplemental photoprotective action to discover products that can increase the sun protection factor (SPF) and stability [3]. Besides, the cosmetic and personal care market has been driven, toward natural ingredients for safer cosmetics or free of harmful chemicals. Several natural resources provide antioxidant, antimicrobial and anti-enzymatic properties. Therefore, natural UV filters and natural preservatives might be useful to prevent the adverse effects of artificial preservatives such as hypersensitivity, allergy, asthma, neurological damage, and cancer [4]. A. catechu is a Thai herb belonging to the Fabaceae family [5]. This plant is a thorny tree which grows up to $15 \mathrm{~m}$ ( $50 \mathrm{ft}$.) in height. Flowers are pale yellow, fruits show flat brown pods, with the triangular beak at the apex, shiny, narrowed at base. There are 3-10 seeds per pod [6]. The major components of the A. catechu heartwood are catechin. Catechins are also a group of natural UV filters [7]. Catechu (or cutch), a hot water extract of red heartwood of A. catechu is the brown powder with the bitter taste. The A. catechu heartwood utilized with betel leaves for chewing. Additionally, A. catechu has several medicinal properties such as immune-modulatory, sore throat, anti-inflammatory, anti-viral, anti-microbial activities and wound healing $[8,9]$. A Leaf methanol extract of $A$. catechu provided antioxidant, DNA protective and antiproliferative properties [10].

A 90-day oral safety study was conducted and showed the safety on a combination of S. baicalensis and A. catechu product in rats [11]. Moreover, a dose of $1000 \mathrm{mg} / \mathrm{kg} /$ day was studied. There was no adverse-effect observed. Furthermore, no adverse effects of $A$. catechu heartwood extracts have been reported in human subjects and animals [12-16]. Therefore, A. catechu should be a good candidate for inspiration and innovation of an efficacy whitening cream. The ultimate goal of this research was to ensure and present the efficacy of $A$. catechu whitening cream as being a premium standard whitening cream.

\section{MATERIALS AND METHODS}

\section{Plant material}

A. catechu heartwood was gathered from A. catechu plantation in Wang Nam Khiao District, Nakhon Ratchasima Province, Thailand, in June 2016 in which the plant grows widely under natural condition. The heartwoods authenticated with a voucher specimen number of PNU/P/023 at the Department of Biological, Phranakorn Rajabhat University. The ethanolic extract was the extract under the optimal extraction conditions reported by Oraphan [17].

\section{Whitening cream formulation}

The formulation strategy of $A$. catechu whitening cream was to use a combination of silicone, chemical UV filter; ethylhexyl 
methoxycinnamate and physical UV filter; titanium dioxide and natural UV-filter ethanolic extract of A. catechu heartwood.

Whitening creams were formulated by mixing Part A (Aqueous Phase; Distilled Water, Propylene Glycol, Sodium Chloride) and B (Silicone Phase; Phenoxyethanol, Cyclopentasiloxane and Dimethicone/Vinyl Dimethicone Crosspolymer, Cyclopentasiloxane, and Cyclohexasiloxane, Cyclopentasiloxane and PEG/PPG-18/18 Dimethicone, Ethylhexyl Methoxycinnamate, Titanium Dioxide, and Talcum) separately. The aqueous phase was gently added to part B, while it was homogenizing at $2000 \mathrm{rpm}$. Then, Part C (A. catechu extract) was added to formulate the whitening creams. When the whitening creams were formed and cooled, the fragrance was gently added at room temperature and mixed until it was homogenous.

Fourteen whitening creams were prepared under the different conditions (table 1) to compare the stability resultants between adding preservative and whitening cream without preservative, different concentrations of the A. catechu heartwood extract and adding chemical and physical UV filters and without the UV filters.

Table 1: Ingredients for each formulation

\begin{tabular}{|c|c|c|c|c|c|c|c|c|c|c|c|c|c|c|c|}
\hline \multirow[t]{2}{*}{ No. } & \multirow[t]{2}{*}{ Ingredients } & \multicolumn{14}{|c|}{ Formulation code } \\
\hline & & F1 & F2 & F3 & F4 & F5 & F6 & F7 & F8 & F9 & F10 & F11 & F12 & F13 & F14 \\
\hline 1 & Distilled Water & 69.54 & 69.30 & 69.00 & 69.40 & 69.30 & 69.40 & 69.20 & 69.22 & 69.11 & 71.00 & 71.00 & 69.11 & 71.00 & 69.20 \\
\hline 2 & Propylene Glycol & 1.51 & 1.95 & 1.55 & 1.73 & 1.95 & 1.73 & 1.52 & 1.52 & 1.53 & 1.69 & 1.59 & 1.53 & 1.59 & 1.52 \\
\hline 3 & Sodium Chloride & 0.76 & 0.75 & 0.78 & 0.78 & 0.75 & 0.78 & 0.75 & 0.75 & 0.75 & 0.78 & 0.78 & 0.75 & 0.78 & 0.75 \\
\hline 4 & $\begin{array}{l}\text { Phenoxyethanol } \\
\text { (preservative) }\end{array}$ & 0.76 & 0.81 & 0.80 & 0.94 & 0.81 & 0.94 & 2.58 & - & - & - & - & - & - & - \\
\hline 5 & $\begin{array}{l}\text { Cylopentasiloxane } \\
\text { (and) } \\
\text { Dimethicone/Vinyl } \\
\text { Dimethicone cross } \\
\text { polymer }\end{array}$ & 11.25 & 11.28 & 11.30 & 11.14 & 11.28 & 11.14 & 11.29 & 11.18 & 11.26 & 11.32 & 11.25 & 11.26 & 11.25 & 11.29 \\
\hline 6 & $\begin{array}{l}\text { Cyclopentasiloxane } \\
\text { (and) } \\
\text { Cyclohexasiloxane }\end{array}$ & 7.55 & 7.60 & 7.50 & 7.68 & 7.60 & 7.68 & 7.55 & 7.65 & 7.53 & 7.62 & 7.56 & 7.53 & 7.56 & 7.55 \\
\hline 7 & $\begin{array}{l}\text { Cyclopentasiloxane } \\
\text { (and) PEG/PPG- } \\
\text { 18/18 Dimethicone }\end{array}$ & 5.28 & 5.25 & 5.25 & 5.37 & 5.25 & 5.37 & 5.29 & 5.29 & 5.43 & 5.48 & 5.26 & 5.43 & 5.26 & 5.29 \\
\hline 8 & $\begin{array}{l}\text { Ethylhexyl } \\
\text { Methoxycinnamate } \\
\text { (Chemical UV } \\
\text { filters) }\end{array}$ & 3.75 & 3.75 & 3.75 & 3.75 & 3.75 & 3.75 & - & 3.75 & 3.76 & 3.76 & 3.75 & 3.76 & 3.75 & - \\
\hline 9 & $\begin{array}{l}\text { Titanium Dioxide } \\
\text { (Physical UV filters) }\end{array}$ & 0.08 & 0.08 & 0.08 & 0.08 & 0.08 & 0.08 & - & 0.08 & 0.08 & 0.08 & 0.08 & 0.08 & 0.08 & - \\
\hline 10 & Talcum & 0.08 & 0.07 & 0.08 & 0.08 & 0.07 & 0.08 & 0.08 & 0.08 & 0.08 & 0.08 & 0.08 & 0.08 & 0.08 & 0.08 \\
\hline 11 & Fragrance & 0.01 & 0.01 & 0.01 & 0.01 & 0.01 & 0.01 & 0.01 & 0.01 & 0.01 & 0.01 & 0.01 & 0.01 & 0.01 & 0.01 \\
\hline 12 & $\begin{array}{l}\text { Acacia catechu } \\
\text { heartwood Extract }\end{array}$ & - & 0.13 & 0.09 & 0.08 & 0.06 & 0.05 & 0.08 & - & 0.13 & 0.09 & 0.08 & 0.06 & 0.05 & 0.08 \\
\hline
\end{tabular}

\section{Inhibition of tyrosinase activity}

The tyrosinase inhibitory activity used a modified method of that performed by Batubara [18]. Inhibition of tyrosinase activity measurements performed on a Microplate Reader (Biotek Synergy HT, USA). The test samples, L-DOPA, and tyrosinase enzyme solutions were dissolved in $20 \mathrm{mmol}$ phosphate buffer solution of $\mathrm{pH}$ 6.8. The activity of mushroom tyrosinase performed in 96-well plates. The reaction mixture consisted of $150 \mu \mathrm{l}$ of $20 \mathrm{mmol}$ phosphate buffer at $\mathrm{pH} 6.8,50 \mu \mathrm{l}$ of a test sample solution, and $50 \mu \mathrm{l}$ of mushroom tyrosinase $(100 \mathrm{unit} / \mathrm{ml}$, E. C. 1.14.18.1, Sigma). The mixture was pre-incubated at $25^{\circ} \mathrm{C}$ for $10 \mathrm{~min}$. Subsequently, $20 \mu \mathrm{l}$ of $2.5 \mathrm{mmol} \mathrm{L}$-DOPA added, and the mixture incubated for $60 \mathrm{~min}$ at $37^{\circ} \mathrm{C}$. During the reaction, L-DOPA converted to dopachrome, which resulted in a change in color from colorless to be orange. This change measured, through absorbance at $490 \mathrm{~nm}$. After incubation at $37{ }^{\circ} \mathrm{C}$ for 60 min, the absorbance at $490 \mathrm{~nm}$ was determined using a microplate reader. The tyrosinase inhibitory percentages were calculated at the concentration of $120 \mu \mathrm{g} / \mathrm{ml}$ by Kojic acid used as a positive control. Percentages of tyrosinase inhibitory activity calculated as following the equation:

$$
\% \text { Tyrosinase inhibitory activity }=\left(\frac{A_{0}-A_{1}}{A_{0}}\right) \times 100
$$

Where $A_{0}$ refers to the absorbance of the control solution, and $A_{1}$ represents the absorbance of the sample

\section{Determination of the in vitro sun protection factor}

Siliva report was slightly modified to determine the in vitro sun protection factor [19]. The investigated whitening creams were dissolved in methanol: water (6:4) and diluted to 150 $\mu \mathrm{g} / \mathrm{ml}$. SPF measurements performed on a Microplate Reader (Biotek Synergy HT, USA). The measurements were made by switching to xenon flash lamp and a monochromator for wavelength selection. Scanning spectra of six whitening creams which SPF standardized and samples in the solution were obtained by running from 320 to $290 \mathrm{~nm}$ (at $5 \mathrm{~nm}$ intervals). The UV-absorbance of the whitening creams which SPF standardized, used as standard whitening creams for calculation of the correction factor (CF). The equation was proposed by Mansur [20] and used to calculate the SPF values for whitening cream samples. Mansur's method is simple and easily reproducible.

$$
S P F=C F \times \sum_{290}^{320} E E(\lambda) \times I(\lambda) \times a b s(\lambda)
$$

Where $\mathrm{CF}$ is correction factor, determined by six whitening creams which SPF standardized; EE $(\lambda)$ the erythemal efficiency spectrum; $I$ $(\lambda)$ the solar simulator spectrum as measured with a calibrated spectrometer; $\sum_{200}^{320} E E(\lambda) \times I(\lambda)=290-320 \mathrm{~nm}$ in $5 \mathrm{~nm}$ increments; abs $(\lambda)$ is the spectrometer measure of the whitening cream absorbance. The absorbance has taken in triplicate at each point. Table 2 shows the normalized values of the product function used in this research. 
Table 2: The normalized product function used in the calculation of SPF data

\begin{tabular}{ll}
\hline Wavelength (nm) & EExI (normalized)* \\
\hline 290 & 0.0150 \\
295 & 0.0817 \\
300 & 0.2874 \\
305 & 0.3278 \\
310 & 0.1864 \\
315 & 0.0839 \\
320 & 0.0180 \\
Total & $=1.000$ \\
\hline
\end{tabular}

*EE: erythemal efficiency spectrum; I: solar simulator intensity spectrum

\section{Stability test}

Accelerated stability test; whitening creams which had the highest concentration of A. catechu with and without preservative (F2, F9), were prepared in replicates $(\mathrm{n}=3)$ and tested the stability under the different temperature $\left(5^{\circ} \mathrm{C} \pm 2{ }^{\circ} \mathrm{C}, 25^{\circ} \mathrm{C} \pm 2{ }^{\circ} \mathrm{C}\right.$ and $\left.40{ }^{\circ} \mathrm{C} \pm 2{ }^{\circ} \mathrm{C}\right)$ for 28 days. Color, liquefaction and phase separation changes using centrifuged at $5000 \mathrm{rpm}$ for ten minutes, were investigated.

Normal stability test; stability testing of the developed A. catechu whitening cream was evaluated and monitored the appearance (color, liquefaction, and phase separation changes), then centrifuged at $3000 \mathrm{rpm}$ for thirty minutes. The stability was investigated, under the different temperature (kept in the refrigerator, ambient temperature and outdoor for 3 months).

\section{Patch testing}

The irritation evaluation was studied using patch testing. The researchers recruited 20 healthy adult volunteers with no underlying skin disease or skin lesion in the test area. Inclusion criteria were participants had normal skin and not used any antiallergic or steroid medication, older than 18 years old, non-pregnant, and not breastfeeding. Exclusion criteria were the use of a topical medication containing steroids to treat skin diseases, subjects with severe skin-related pathologies and abnormalities, such as erythema, eczema. All volunteers were informed of objectives, test procedures, and possible adverse effects, and rewarded for their participation. The Ethics Committee of Phranakorn Rajabhat University, Bangkok, Thailand, approved the present method (AF0506 study code: $60-23$ ). All volunteers have given consent before entering the study. Volunteers have the right to withdraw from the study at any time without consequence or penalty.

\section{Testing of satisfaction}

In order to investigate the satisfaction of the products, all volunteers form irritation testing shown their satisfaction using questionnaires.
The five-rating scale questionnaire has consisted of two parts, personal data, and product data. Questions in personal data were about gender, age, and type of skin. While, product questions were the sensorial evaluation of the whitening cream (texture, color, odor, consistency), improvement in the skin upon use, skin nourishment, and satisfaction with the whitening creams. The five-rating scale used a scale that ranged from 1 (Strongly Dissatisfied) to 5 (Strongly Satisfied). Additionally, the developed product was compared satisfaction with the commercial product by the blinded experiment.

\section{RESULTS AND DISCUSSION}

\section{Whitening cream formulation}

Fourteen whitening creams were prepared using silicone-based. The fresh, smooth and soft textures of the whitening creams from the different formulations were represented in fig.1.
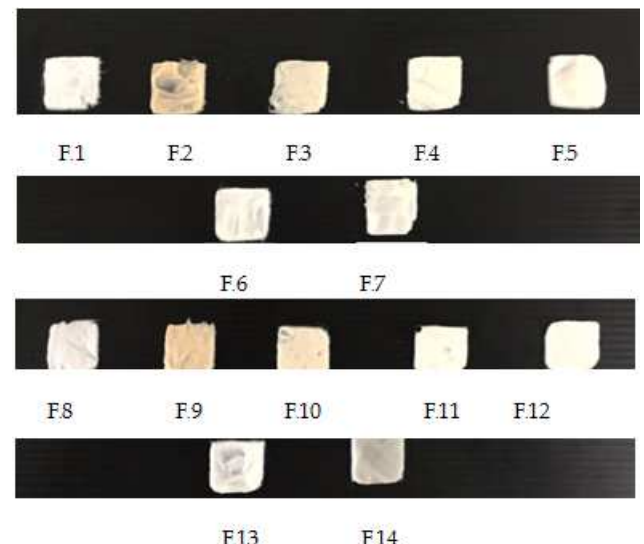

Fig. 1: Appearance of the whitening creams

Table 3: The percentages of tyrosinase inhibition at a concentration of $120 \mu \mathrm{g} / \mathrm{ml}$

\begin{tabular}{lll}
\hline No. & \% Tyrosinase inhibition at a concentration of $\mathbf{1 2 0} \boldsymbol{\mu} \mathbf{g} \mathbf{m l}$ & \\
\cline { 2 - 3 } & A. catechu extract & Kojic acid \\
\hline 1 & 62.03 & 98.73 \\
2 & 59.74 & 98.70 \\
3 & 62.96 & 98.77 \\
Average & 61.58 & 98.73 \\
SD & 1.66 & 0.04 \\
$\%$ RSD & 2.69 & 0.04 \\
\hline
\end{tabular}

Note: Number of experiments: 3

\section{Inhibition of tyrosinase activity}

The present study aimed to determine the potential of $A$. catechu whitening cream. The tyrosinase inhibition of the extract was studied in triplicate.

The $A$. catechu extract showed the strong tyrosinase inhibitory activity with the percentage of inhibition of 61.58 at a concentration of $120 \mu \mathrm{g} / \mathrm{ml}$ compared to a positive control of kojic acid (98.73\% inhibition) at the same concentration of $120 \mu \mathrm{g} / \mathrm{ml}$ (table 3).
Interestingly, the inhibitory activity of $A$. catechu extract was about two times weaker than kojic acid compared an anti-tyrosinase activity of ellagic acid-rich pomegranate peel extract which was about seven times weaker than kojic acid [21]. In another study, the percentages of tyrosinase inhibitory activity of kojic acid and curcumin at a concentration of $120 \mu \mathrm{g} / \mathrm{ml}$ were about 84 and 72 , respectively [22]. The tyrosinase inhibitory ability of the phenolic compounds strongly influenced by the structure of the phenolic compounds. The inhibition percentage of the ethanol extract of 
Matoa leaves and stem bark with a final concentration of $200 \mu \mathrm{g} / \mathrm{ml}$, was $24.54 \pm 0.22 \%$ and $21.93 \pm 0.57 \%$, respectively. The value of the inhibition percentage showed that the inhibitory ability of the tyrosinase of the ethanol extract of Matoa leaves and stem bark was much weaker than that of kojic acid $(6.63 \mu \mathrm{g} / \mathrm{ml})$ [23].

\section{Determination of the in vitro sun protection factor}

The SPF values represented in table 4 . Table 4 represented that an increasing of $A$. catech $u$ causes SPF to increase. A good positive correlation found between SPF values and A. catechu contents. Pearson Correlation was 0.983 with the correlation coefficient of significant at the 0.01 level. The highest SPF value was 30.344 from sample 2, that corresponds to a 97 percent UVB-protection [24]. The lowest SPF value was 24.143 from sample 7 . The average SPF values of the samples with and without preservative were 28.347 and 28.549 , respectively. Moreover, the results show a high SPF value (24) even no synthetic UV-filters. Impressively, the results of this research reveal high SPF values compared with other natural whitening creams. SPFs of methanol solutions of flowers of Calendula officinale and flowering tops of Hypericumperforatum were 12.01 and 12.21, respectively [25]. SPF values of the products containing extracts from Menthapiperita (Leaves), Azadirachtaindica (Leaves) Oscimum sanctum (Leaves), Aloe vera (Leaves), Lycopersicon esculantum (fruits), and Carica papaya (fruits) were $8.184,4.368,2.904,5.437,6.083$, and 2.310 , respectively [26]. Their SPF values of the Zanthoxylumrhetsa whitening cream were $3.60 \pm 0.28$ (F1) and 6.90 \pm 0.57 (F2) [27]. Moringaoleifera sun care demonstrated SPF 2 [28]. The carrot and coconut cream containing $2 \%$ of coconut ethyl acetate extract showed the lowest SPF value of 0.64 [29]. The experimental results performed in the triplicate.

The data recorded as mean+standard derivation. The analysis of variance performed by ANOVA. The significant differences between means of the concentrations of $A$. catechu vs. sun protection properties were determined. A good positive correlation found between SPF values and A. catechu contents. Pearson Correlation was 0.98 and the correlation coefficient was significant at the 0.01 level.

Table 4: Sun protection factor of the whitening cream samples

\begin{tabular}{|c|c|c|c|}
\hline Whitening cream with preservative & SPF & Whitening cream without preservative & SPF \\
\hline F1. Control whitening cream without $A$. catechu & $27.797 c \pm 0.009$ & F8. Control whitening cream without $A$. catechu & $28.278 c \pm 0.133$ \\
\hline F2. A. catechu whitening cream & $30.344 \mathrm{a} \pm 0.011$ & F9. A. catechu whitening cream & $30.341 \mathrm{a} \pm 0.005$ \\
\hline F3. A. catechu whitening cream & $29.597 \mathrm{~b} \pm 0.010$ & F10. A. catechu whitening cream & $29.797 b \pm 0.014$ \\
\hline F4. A. catechu whitening cream & $29.259 b \pm 0.015$ & F11. A. catechu whitening cream & $29.110 \mathrm{~b} \pm 0.014$ \\
\hline F5. A. catechu whitening cream & $28.945 b \pm 0.054$ & F12. A. catechu whitening cream & $29.079 b \pm 0.023$ \\
\hline F6. A. catechu whitening cream & $28.344 \mathrm{c} \pm 0.006$ & F13. A. catechu whitening cream & $28.858 b \pm 0.029$ \\
\hline $\begin{array}{l}\text { F7. A. catechu whitening cream without physical } \\
\text { and chemical UV filters }\end{array}$ & $24.143 \mathrm{~d} \pm 0.009$ & $\begin{array}{l}\text { F14. A. catechu whitening cream without physical } \\
\text { and chemical UV filters }\end{array}$ & $24.381 \mathrm{~d} \pm 0.020$ \\
\hline Average & 28.347 & Average & 28.549 \\
\hline
\end{tabular}

Note: ${ }^{\boldsymbol{a}-\boldsymbol{d}}$ Averages for different SPF values with different letters $(\mathrm{P}<0.05)$ : Number of experiments: 3: Data given in mean+SD

\section{Stability testing}

For accelerated stability testing for $28 \mathrm{~d}$, the liquefaction and color of the samples were slightly changed after $21 \mathrm{~d}$ as shown in table 5. Besides, the normal stability under the different conditions (room temperature, refrigerator and outdoor) was investigated.
The color and liquefaction had slightly changed after 1 mo for sample F9 (sample without preservative), while the sample F9 was separated after $3 \mathrm{mo}$ as represented in table 6 . However, no changes in color, liquefaction and phase separation were observed for the developed whitening cream after stored in the refrigerator for three months.

Table 5: Physical characteristics of $F 2$ and F9, formulations kept at $5 \pm 2{ }^{\circ} \mathrm{C}, 25 \pm 2{ }^{\circ} \mathrm{C}$ and $40 \pm 2{ }^{\circ} \mathrm{C}$

\begin{tabular}{|c|c|c|c|c|c|c|c|c|c|c|c|c|c|c|c|}
\hline & & \multicolumn{2}{|c|}{ Fresh } & \multicolumn{2}{|c|}{$24 \mathrm{~h}$} & \multicolumn{2}{|l|}{$3 \mathrm{~d}$} & \multicolumn{2}{|c|}{$7 \mathrm{~d}$} & \multicolumn{2}{|c|}{$14 d$} & \multicolumn{2}{|c|}{$21 d$} & \multicolumn{2}{|c|}{$28 d$} \\
\hline & & F2 & F9 & F2 & F9 & F2 & F9 & F2 & F9 & F2 & F9 & F2 & F9 & F2 & F9 \\
\hline \multirow[t]{3}{*}{ Liquefaction } & $5{ }^{\circ} \mathrm{C}$ & $\mathrm{N}$ & $\mathrm{N}$ & $\mathrm{N}$ & $\mathrm{N}$ & $\mathrm{N}$ & $\mathrm{N}$ & $\mathrm{N}$ & $\mathrm{N}$ & $\mathrm{N}$ & $\mathrm{N}$ & $\mathrm{N}$ & $\mathrm{N}$ & $\mathrm{N}$ & $\mathrm{N}$ \\
\hline & $25^{\circ} \mathrm{C}$ & $\mathrm{N}$ & $\mathrm{N}$ & $\mathrm{N}$ & $\mathrm{N}$ & $\mathrm{N}$ & $\mathrm{N}$ & $\mathrm{N}$ & $\mathrm{N}$ & $\mathrm{N}$ & $\mathrm{N}$ & $\mathrm{N}$ & $\mathrm{N}$ & $\mathrm{N}$ & $\mathrm{N}$ \\
\hline & $40^{\circ} \mathrm{C}$ & $\mathrm{N}$ & $\mathrm{N}$ & $\mathrm{N}$ & $\mathrm{N}$ & $\mathrm{N}$ & $\mathrm{N}$ & $\mathrm{N}$ & $\mathrm{N}$ & $\mathrm{N}$ & $\mathrm{N}$ & $\mathrm{N}$ & SC & $\mathrm{N}$ & SC \\
\hline \multirow[t]{3}{*}{ Color } & $5^{\circ} \mathrm{C}$ & PY & PY & PY & PY & PY & PY & PY & PY & PY & PY & PY & PY & PY & PY \\
\hline & $25^{\circ} \mathrm{C}$ & PY & PY & PY & PY & PY & PY & PY & PY & PY & PY & PY & PY & PY & PY \\
\hline & $40^{\circ} \mathrm{C}$ & PY & PY & PY & PY & PY & PY & PY & PY & PY & PY & PY & SWY & PY & SWY \\
\hline \multirow[t]{3}{*}{ Phase separation } & $5{ }^{\circ} \mathrm{C}$ & $\mathrm{N}$ & $\mathrm{N}$ & $\mathrm{N}$ & $\mathrm{N}$ & $\mathrm{N}$ & $\mathrm{N}$ & $\mathrm{N}$ & $\mathrm{N}$ & $\mathrm{N}$ & $\mathrm{N}$ & $\mathrm{N}$ & $\mathrm{N}$ & $\mathrm{N}$ & $\mathrm{N}$ \\
\hline & $25^{\circ} \mathrm{C}$ & $\mathrm{N}$ & $\mathrm{N}$ & $\mathrm{N}$ & $\mathrm{N}$ & $\mathrm{N}$ & $\mathrm{N}$ & $\mathrm{N}$ & $\mathrm{N}$ & $\mathrm{N}$ & $\mathrm{N}$ & $\mathrm{N}$ & $\mathrm{N}$ & $\mathrm{N}$ & $\mathrm{N}$ \\
\hline & $40^{\circ} \mathrm{C}$ & $\mathrm{N}$ & $\mathrm{N}$ & $\mathrm{N}$ & $\mathrm{N}$ & $\mathrm{N}$ & $\mathrm{N}$ & $\mathrm{N}$ & $\mathrm{N}$ & $\mathrm{N}$ & $\mathrm{N}$ & $\mathrm{N}$ & $\mathrm{N}$ & $\mathrm{N}$ & $\mathrm{N}$ \\
\hline
\end{tabular}

$\mathrm{N}=$ No change; $\mathrm{SC}=$ Slight change; $\mathrm{SP}=$ Separate; $\mathrm{PY}=$ Pale yellow; SYW = Soft yellowish white; $\mathrm{YW}=$ Yellowish white = Yellow; $\mathrm{W}=\mathrm{White}$.

Table 6: Physical characteristics of F2 and F9, formulations kept in Room temperature, Refrigerator, and Outdoor

\begin{tabular}{|c|c|c|c|c|c|c|c|c|c|c|c|}
\hline & & \multicolumn{2}{|c|}{ Fresh } & \multicolumn{2}{|c|}{$24 \mathrm{~h}$} & \multicolumn{2}{|c|}{$1 \mathrm{mo}$} & \multicolumn{2}{|l|}{$2 \mathrm{mo}$} & \multicolumn{2}{|l|}{$3 \mathrm{mo}$} \\
\hline & & F2 & F9 & F2 & F9 & F2 & F9 & F2 & F9 & F2 & F9 \\
\hline \multirow[t]{3}{*}{ Liquefaction } & Room temperature & $\mathrm{N}$ & $\mathrm{N}$ & $\mathrm{N}$ & $\mathrm{N}$ & $\mathrm{N}$ & $\mathrm{N}$ & $\mathrm{N}$ & SC & $\mathrm{SC}$ & SC \\
\hline & Refrigerator & $\mathrm{N}$ & $\mathrm{N}$ & $\mathrm{N}$ & $\mathrm{N}$ & $\mathrm{N}$ & $\mathrm{N}$ & $\mathrm{N}$ & $\mathrm{N}$ & $\mathrm{N}$ & $\mathrm{N}$ \\
\hline & Outdoor & $\mathrm{N}$ & $\mathrm{N}$ & $\mathrm{N}$ & $\mathrm{N}$ & $\mathrm{N}$ & $\mathrm{N}$ & $\mathrm{N}$ & SC & SC & SC \\
\hline \multirow[t]{3}{*}{ Color } & Room temperature & PY & PY & PY & PY & PY & PY & PY & PY & SYW & SYW \\
\hline & Refrigerator & PY & PY & PY & PY & PY & PY & PY & PY & PY & PY \\
\hline & Outdoor & PY & PY & PY & PY & PY & PY & SYW & SYW & SYW & YW \\
\hline \multirow{3}{*}{ Phase separation } & Room temperature & $\mathrm{N}$ & $\mathrm{N}$ & $\mathrm{N}$ & $\mathrm{N}$ & $\mathrm{N}$ & $\mathrm{N}$ & $\mathrm{N}$ & $\mathrm{N}$ & $\mathrm{N}$ & $\mathrm{N}$ \\
\hline & Refrigerator & $\mathrm{N}$ & $\mathrm{N}$ & $\mathrm{N}$ & $\mathrm{N}$ & $\mathrm{N}$ & $\mathrm{N}$ & $\mathrm{N}$ & $\mathrm{N}$ & $\mathrm{N}$ & $\mathrm{N}$ \\
\hline & Outdoor & $\mathrm{N}$ & $\mathrm{N}$ & $\mathrm{N}$ & $\mathrm{N}$ & $\mathrm{N}$ & $\mathrm{N}$ & $\mathrm{N}$ & $\mathrm{N}$ & $\mathrm{N}$ & SP \\
\hline
\end{tabular}

$\mathrm{N}=$ No change; $\mathrm{SC}=$ Slight change; $\mathrm{SP}=$ Separate; PY = Pale yellow; SYW = Soft yellowish white; YW = Yellowish white; Y = Yellow; W = White

\section{Patch testing}

For the irritation evaluation, patch testing under the clinical observation and approved protocol by The Ethics Committee of Phranakorn Rajabhat University. Twenty volunteers aged from 18 to 34 years old, were selected to participate the irritation evaluation. 
The whitening cream with highest $A$. catechu concentration and without preservative and synthetic UV filters (F9), was used to investigate. Among the twenty volunteers, eighteen volunteers had no skin irritation, while one of them had redness (Transient) and another one had erythema or very slight irritation to the developed whitening creams.

\section{Testing of satisfaction}

The analysis of satisfaction toward the A. catechu whitening cream showed the high satisfaction level (3.94) in overall aspect (texture, consistency, sensory and odor). When considering in each aspect, the results indicated that the highest average value was the texture of the whitening cream (4.05) followed by the sensory (4.00), the consistency (3.95) and the least was the odor (3.75). Averages of satisfaction of the developed whitening and the commercial product were 3.94 and 3.78 , respectively, as shown in table 7. Additionally, there was no statistically significant difference for the satisfaction, between $A$. catech $u$ whitening creams and commercial whitening creams $(p>0.05)$.

Table 7: Satisfaction evaluation from five-rating scale questionnaire

\begin{tabular}{llllll}
\hline \multirow{2}{*}{ Whitening cream } & \multicolumn{4}{l}{ Average of the satisfaction score on each aspect(n=20) } & \multicolumn{2}{l}{ Average } \\
\cline { 2 - 5 } & Texture & Consistency & Sensory & Odor \\
\hline Commercial whitening cream & $3.90+0.55$ & $3.85+0.49$ & $3.90+0.64$ & $3.50+0.61$ & 3.78 \\
A. catechu whitening cream with preservative (F2) & $4.05+0.69$ & $3.95+0.22$ & $4.00+0.56$ & $3.75+0.55$ & 3.94 \\
\hline
\end{tabular}

Note: Number of experiments: 20: Data given in mean+SD

\section{CONCLUSION}

This current study presented high-efficiency whitening cream. Combination of natural and synthetic UV filters could provide synergistic efficacy for a novel cosmeceutical of $A$. catechu whitening cream. A. catechu whitening cream without synthetic UV filters provided high SPF, the SPF value of 24 . The A. catechu extract showed the strong tyrosinase inhibitory activity with the percentage of inhibition of 61.58 at a concentration of $120 \mu \mathrm{g} / \mathrm{ml}$. A. catechu whitening cream without preservative provided good stability for three months. Moreover, patch testing and satisfaction of the developed whitening compared with the commercial product were studied. The developed whitening provided very good results. Therefore, the A. catechu whitening cream by this work shows the readiness to be a premium commercial product in the near future.

\section{FUNDING}

This research was funded by the Thailand Research Fund (grant no. MRG5480018), National Research Council of Thailand to Oraphan Anurukvorakun (grant no. 709793).

\section{ACKNOWLEDGMENT}

Instrument and other facilities were supported by the Faculty of Science and Technology, Phranakorn.

\section{AUTHORS CONTRIBUTIONS}

O. A. conceived and designed the experiments; O. A.,N. L. and R. B. performed the experiments; 0 . A. analyzed the data; 0 . A. wrote the manuscript; O. A. N. L. and R. B. acquired fund.

\section{CONFLICTS OF INTERESTS}

All authors have none to declare

\section{REFERENCES}

1. Saewan N, Jimtaisong A. Photoprotection of natural flavonols. J Appl Pharm Sci 2013;3:129-41.

2. Ebrahimzadeh AM, Enayatifard R, Khalili M, Ghaffarloo M, Saeedi M, Charati YJ. Correlation between sun protection factor and antioxidant activity, phenol and flavonoid contents of some medicinal plants. Iran J Pharm Res 2014;13:1041-7.

3. Choquenet B, Couteau C, Paparis E, Coiffard LJM. Quercetin and rutin as potential whitening creamagents: determination of efficacy by an in vitro method. J Nat Prod 2008;71:1117-8.

4. Anand SP, Sati N. Artificial preservatives and their harmful effects: looking toward nature for safer alternatives. Int J Pharm Sci Res 2013;4:2496-501.

5. Ismail S, Asad M. Immunomodulatory activity of Acacia catechu. Indian J Physiol Pharmacol 2009;53:25-31.

6. Thakur AV, Ambwani S, Ambwan TK. Preliminary phytochemical screening and GC-MS analysis of leaf extract of Acacia catechu (L. f.) willd. Int J Herb Med 2018;6:81-5.

7. Lee XZ, Liang YR, Chen H, Lu JL, Liang HL, Huang FP, et al. Alleviation of UV-B stress in arabidopsis using tea catechins. Afr J Biotechnol 2008; 7:4111-5.
8. Chirumbolo $\mathrm{S}$. The role of quercetin, flavonols, and flavones in modulating inflammatory cell function. Inflamm Allergy Drug Targets 2010;9:263-85.

9. Patal JD, Kumar V, Bhatt SA. Antimicrobial screening and phytochemical analysis of the resin part of Acacia catechu. Pharm Biol 2009;49:34-7.

10. Kumar R, Arora R, Mahajan J, Mahey S, Arora S. Polyphenols from cutch tree (Acacia catechu willd.): normalize in vitro oxidative stress and exerts anti-proliferative activity. Braz Arch Biol Technol 2018;61:1-13.

11. Yimam M, Zhao Y, Ma W, Jai QD, Shin JH. 90-day oral toxicity study of UP446, a combination of defined extracts of Scutellariabaicalensis and Acacia catechu, in rats. Food Chem Toxicol 2010;48:1202-9.

12. Burnett BP, Jia Q, Zhao Y, Levy RM. A medicinal extract of Scutellariabaicalensis and Acacia catechu acts as a dual inhibitor of cyclooxygenase and 5-lipoxygenase to reduce inflammation. J Med Food 2007;10:442-51.

13. Morgan SL, Baggott J, Moreland L, Desmond R, Kendrach AC. The safety of flavocoxid, a medical food, in the dietary management of knee osteoarthritis. J Med Food 2009;12:1143-8.

14. Levy RM, Khokhlov A, Kopenkin S. Efficacy and safety of flavocoxid, a novel therapeutic, compared to naproxen: a randomized multicenter controlled trial in subjects with osteoarthritis of the knee. Adv Ther 2010;27:731-42.

15. Nadumane VK. Evaluation of the anticancer and cytotoxic potentials of Acacia catechu extracts in vitro. J Nat Pharm 2011;2:190-5.

16. Yimam M, Brownell L, Pantier M, Jia Q. UP446, analgesic, and anti-inflammatory botanical composition. Pharmacognosy Res 2013;5:139-45.

17. Anurukvorakun 0 , Vajragupta 0 . The confirmation of flavonoids from Acacia catechu (L. f.) willd as potential whitening cream agents under the twolevel factorial design. Int J Pharm Photon 2014;105:420-6.

18. Batubara I, Darusman LK, Mitsunaga T, Rahminiwati M, Djauhari E. Potency of Indonesian medicinal plants as tyrosinase inhibitor and antioxidant agent. J Biol Sci 2010;10:138-44.

19. Siliva VVD, Ropke CD, Almeida RLD, Miranda DV, Kera CZ, Rivelli DP, et al. Chemical stability and SPF determination of extract gel and photostability of 4-nerolidylcathecol. Int J Pharm 2005;303:125-31.

20. Mansur JS, Breder M, Mansur M, Azulay RD. Determination of the sun protection factor by spectrophotometry. An Bras Dermatol 1986;61:121-4.

21. Nukanya T, ANAN O, Pharkphoom P, Waree T. Development of ellagic acid-rich pomegranate peel extract loaded nanostructured lipid carriers (NICS). Int J Pharm Pharm Sci 2014;6:259-65.

22. Nisakorn S, Anongnuch T, Ampa, Krisada K. Anti-tyrosinase and cytotoxicity activities of curcumin-metal complexes. Int J Pharm Pharm Sci 2014;6:270-3.

23. Rani S, Nur A, Katrin B. Tyrosinase inhibition, 2,2-diphenyl-1picrylhydrazyl radical scavenging activity, and phytochemical screening of fractions and ethanol extract from leaves and stem 
bark of matoa (Pometia Pinnata). Asian J Pharm Clin Res 2017;10:85-9.

24. United States Environmental Protection Agency, United States; 2006:EPA 430-F-06-013.

25. Khazaeli P, Mehrabani M. Screening of sun protective activity of the ethyl acetate extracts of some medicinal plants. Iran J Pharm Res 2008;7:5-9.

26. Gupta D, Malawat T. UV absorbing properties of some plantderived extracts. Res J Chem Environ Sci 2003;1:34-6.

27. Santhanam RK, Akhtar MT, Abas SAF, Ismail IS, Rukayadi Y, Shaari $\mathrm{K}$. Utilization of the ethyl acetate fraction of Zanthoxylumrhetsabark extract as an active ingredient in natural whitening cream formulations. Ind Crops Prod 2017;96:165-72.

28. Baldisserotto A, Buso P, Radice M, Dissette V, Lampronti I, Gambari $\mathrm{R}$, et al. Moringaoleifera leaf extracts as multifunctional ingredients for "natural and organic" whitening creams and photoprotective preparations. Molecules 2018;23:2-16.

29. Kinshasa DR, Mpiana PT. Comparative in vitro sun protection factor (SPF) values of herbal extracts found in kinshasa by ultraviolet spectrophotometry. J Physical Chem Sci 2015;2:1-6 